\title{
A Discussion On Child-centred Education in the Chinese Context
}

\author{
Jinfeng Zhou \\ School of Foreign Languages \\ Anshan Normal University \\ Anshan, China
}

\begin{abstract}
This paper presents a detailed demonstration on the arguments on child-centered education, and much emphasis is put in the Chinese context. It is illustrated that education should definitely be designed basing on children's needs and interests. However, the function of teachers should not be neglected. The instructions by teachers should not be supplanted but supplemented and teachers should serve as co-planners in the teaching process.
\end{abstract}

Keywords—child-centred education; children's need; children's interest; co-planner

\section{INTRODUCTION}

The new pattern of school life which is seen as childcentred education (or progressivism) reflects a fundamental change that has been taking place in education in the last decades. Child-centred education derives from Rousseau's and Dewey's educational theory his influence is massive. In America, his thinking fed directly into many schools, especially in Chicago where one of Dewey's associates eventually became superintendent of schools (Darling 1994). In China, many students studying in the United States took Dewey's idea back to China when they returned. In Britain, progressivism was publicly introduced in the 1960s when the two best known official reports Primary Education in Scotland (the Primary Memorandum) and Children and their Primary Schools (the Plowden Report) were published.

However, a number of academics have been arguing the practical value of child-centred education. As "strong on methods, but weak on aims" is a judgement that has always been expressed on progressivism, Dearden questions whether it is possible at all to be strong on methods if one is weak on aims (Dearden 1976: 53). He also argues that the various desirable ways in which the child should relate to what he does and learns has been too much specified, while the content of the learning has been neglected. McCulloch complains that the "dogmatic orthodoxy" of progressive education "had led directly to educational and social decline" (McCulloch 1997:78)

Therefore, the aim of this paper is to try to argue whether child-centred education is a more appropriate educational theory, and whether there are any insufficient and unpractical aspects.

\section{CHILD-CENTRED EDUCATION}

\section{A. The Origin of Child-Centred Education}

In terms of child-centred education, Jean-Jacques Rousseau is unquestionably the most brilliant exponent in its history. In Emile, Rousseau argues that child is naturally good. Therefore, learning is most effective when it follows the child's interests and needs (Rousseau 1762). "Childhood has its own ways of seeing, thinking, and feeling: nothing is more foolish than to try and substitute our ways" (ibid. 54). He introduces the concept of development stages of the human being: infancy, childhood, pre-adolescence, young adult, and maturity and indicates that each stage has appropriate learning activities and education should proceed long natural lines (Rousseau 1762). He complains, "The wisest writers devote themselves to what a man ought to know, without asking what a child is capable of learning"(ibid. 1). He further points out that there must be agreement between the teacher's educational programme and nature's development programme (ibid. 6).

Here I would agree with Rousseau that education should be designed to make it in accord with the nature of the learner and education should proceed along with children's growth stage. I believe it just completely fit in with the present education system-infant school, primary school, secondary school and higher institute.

\section{B. The Development of Child-Centred Education}

Another influential educator in this arena is John Dewey. He helps to 'legitimate child-centred educational theory' and develops his ideas in a way that 'give them academic credibility' (Darling 1994: 25). Dewey's thinking is strongly influenced by the idea of social progress. He advocates that education has a social function and there ought to be constant interaction between school and society (Dewey 1916). Learning should take place through group activities-the running of shops, the cultivation of gardens, the staffing of plays or any other planned undertaking, while teachers should participate in the activities, with the distinction between teacher and learner being minimized (Darling 1994). Good teaching, in Dewey's opinion, 'links up with out-of-school activities, interests and problems' (Dewey 1916: 156).

Therefore, for Dewey, the teacher is neither an instructor of passive learners, nor a tester for continuous examinations, nor a referee in a competition, nor an authority on a particular subject. 
In fact, the teacher's job is to arrange proceedings in such a way that learning is encouraged and made easier and the teacher becomes a co-planner of work (Darling 1994).

It can be seen that child (leaner)-centred education advocates education is a matter of personal growth. Education should start from the learner's needs and interests and learner should develop at their own pace. In a word, it is learners who dominate the teacher process. As demonstrated above, childcentred education has attracted numerous supporters, especially those who have suffered a lot from traditional education. However, a number of academics have never stopped questioning its practical value and massive debates have been prevailing.

\section{QUESTIONING CHILD-CENTRED EDUCATION}

In terms of theory, child-centred education has been argued by philosophers and others over the last two hundred years. In terms of practice, it reached a climax in the middle of twentieth century. Therefore, at the same time as changes were taking place in schools, philosophers were themselves undergoing a transformation and they became more critical of it. The critics have been carried out in different styles for different purposes.

\section{A. Children's Need}

As demonstrated in the first section, one of the characteristics of progressive education is that the children's needs dominate the teaching process. Kirk (1982) explains child-centred thinking in these terms: "the primary function of schools was to attend to the needs of pupils: these, and other characteristics of learners themselves, were assumed to be the principle determinants of the curriculum"(p 35). In Primary Education in Scotland, we can find that the first chapter is not devoted to discuss the 'aims of education', but 'the needs of the child'. Concerning secondary education, one of the publications of National Union of Teachers says: "a primary principle in curriculum construction should be to serve individual needs"(quoted in Dearden et al 1972: 48). That is to say, the curriculum should be based on the child's needs. It seems to them that any educational program fails to match the needs of the learner will be unsatisfactory. Consequently, a curriculum which is carefully designed according to children's needs will be the most appropriate one and will evoke children's motivation. However, the problem here is who can tell what children's educational needs are. Is it the children themselves or somebody else?

'Need' by Dearden 'is that a state of affairs conceived of is absent' (Hirst \& White 1998, Vol IV: 256). In addition to the basic physical needs, children have social psychological needs as well, and one of the key features by Dearden is that this kind of need 'is an interpretation of human behaviour at a level of which human beings are unaware' (Hirst \& White 1998, Vol IV: 263). Then I would highlight again that obviously, needs in education is not as simple as the needs for food or toys, and according to Maslow' theory, if children have not had their lower needs satisfied, they are incapable of identifying the upper needs. Therefore, most of time children can not tell their needs without experts' guidance.

Then another question concerning with 'need' is that needsbased curriculum offers no basis for judgement. Dearden (1968) questions that we can not judge if one curriculum is preferable to another as any curriculum can be construed or defended as a needs-based curriculum.

Children, in my opinion, need outside help from teachers or experts to choose sensibly the keenness and clarity of their interest. Teachers, meanwhile, have the duty to consider whether or not a particular interest is desirable and valuable. Children need constantly the kind of confidence to proceed which comes from receiving effective help and this effective help is the educative function of teachers (Wilson, 1998).

Moreover, once a child's interest is identified, we can not expect him to be able to pursue his interest entirely without help. In most cases, children's interests usually last for a comparatively short term. I would like to present an example to show this point more clearly. For instance, nearly every child shows great interest in playing musical instrument. In China, almost every child in urban area has the experience of learning playing piano. However, just a small number of them can keep on till teenagers. Children sometimes can not stay with their interests for a long period as they can not see the future of their interests. Children's interests need help to be sustained.

\section{B. The Aims of Child-Centred Education}

"Strong on methods, but weak on aims" is a judgement that has often been expressed on child-centred educational theory. Child-centred education focuses on developmental stages in child, while what is taught is secondary. R. S Peters complains that child-centred educators are too much concerned with manners and insufficiently with the matters (Standish 2002). It puts much emphasis on the teaching methods and concentrates on the effect on the child himself of what he learns and what he does, whereas it de-emphasizes the subject content. But it would be questioned that without aims what are the criteria of success and failure for judging one's efforts and how could a series of activities be regarded as the expression of a method? Does telling lies good or bad? Well of course it depends on the circumstances and what you are aiming at. Prisoners tell lies to police to avoid punishment, while doctors tell lies to a dying patient to give him a happy end of life. Therefore, we can not make a judgement until we know the aim.

Then what are the aims of child-centred education? Dearden (1976) has grouped them under three main headings: (i) intrinsic interest (eagerness, curiosity, learning to learn, absorption, etc.); (ii) self-expression (expressing one's own individuality, being oneself, etc.); (iii) autonomy (making independent judgements, choosing with confidence, selfdirection, learning by discovery, etc.) (p54). In Dearden's opinion, the child-centred aims are relational rather than prescriptive of content to be learned. They specify the various ways that the child should relate to in learning, and neglect the content of learning. For liberal educators, central in education is the knowledge and understanding, and basic skills are necessary for children to take full advantage of their subsequent education (Dearden 1976). Peters also points out that content of education consists of things worth doing or learning for their own sakes, and he says that: 'only in so far as one has the relevant knowledge and forms of reasoning can a person be creative or critical in, say atomic physics'(Hirst and Peters 1970: 61). In the well-known Harvard Committee 
Report, Liberal educational theory therefore claims: 'By characteristics we mean aims so important as to prescribe how general education should be carried out and which abilities ought to be sought above all others in every part of it'(quoted in Hirst \& White 1998: 249). Therefore, for liberal educators, supreme priority should be given to the acquisition of knowledge within education. Hirst (1998) further points out that to acquire knowledge is to learn to see, to experience the world and to develop the mind. "Grounded in knowledge and understanding, human being thus aspire to live in conformity with what is the case, what is objectively given in human nature and in the environment in which human beings find themselves" (ibid. 385).

Therefore, learning is only possible when they are in the pursuit of our own interests which should be intermittent and life-long.

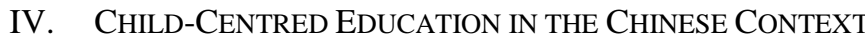

China has been attracting more and more worldwide attention for its rapid development nowadays. Many western academics have been paying attention not only to its economic strategies, but also to its educational theories. What has dominated the Chinese education conception for two thousands and a half years is the Confucian conceptions of learning. In Confucian conception, education is regarded as essential not only for personal improvement but also for social development. Chinese traditional education, therefore, is based on the Confucian classics and involves rote memorization of these classics.

Child-centred education focuses on individual need and interest and regard education as the self-realization of the individual. Curriculum should be designed to meet individual requirement. Similarly, the traditional Chinese education conception is also, to some extent, rich in individualism.

However, tremendous differences exist between the Chinese education and the child-centred education. The most outstanding one is the teaching methods. Child-centred education pays a close attention to teaching manner which involves activities like discussion or group work. Most of time students learn by sitting round tables and the teacher, is more like a facilitator. The Chinese context is more like the traditional education. Students sit by rows while the teacher is mostly standing behind a platform which is more like a barrier between the teacher and students. Knowledge is directly passing down by the teacher with few questions raised by students. Learning mainly depends on students' memorization, and the simplest way is repeating over and over again, making themselves remember. According to the Chinese tradition, most Chinese believe 'practice makes perfect' and learning is a process requiring hard work, effort, and perseverance.

Another essential difference concerns the question 'who is the centre in the teaching process'. There is no doubt that childcentred education regards children as the centre. It sees education as a matter of personal growth, and allows children to develop at their own pace. It advocates that children should learn by doing and playing and what is more important, the teacher should help to cultivate children's own imagination and creativity. Well what has happened in China is on the contrary.
Traditionally, teachers are the absolute ruler and viewed as a father figure. There are many traditional saying reflecting this view, such as: 'One day as your teacher makes somebody your father for life'. The whole teaching process is dominated by teachers.

However, changes have taken place on the relationship between teacher and students. Actually, it was in the 1950s that some educators stress that teachers should arouse students to seek understanding method, and teachers and students are encouraged to learn together. During the Mao period, the view that teacher is not 'the repository of absolute unchallengeable knowledge' was taken to its extreme, and people believe that the relationship should be one of friendship (Schoenhals 1993: 116).

Upon entering the $21^{\text {st }}$ century, tremendous progress has been made to improve the teaching quality. With stress on the cultivation of the students' creativity and practically, in 1999, the Ministry of Education promulgated the Program for Course Reform of Basic Education (Trial) and Experimental Plan for Course Configuration of Compulsory Education and Course Standards (Experimental Version), which started to implement in 2001(National Centre for Education Development Research 2001). The course reform says that emphasis should be put on forming a positive and active learning attitude so as to turn the process of acquiring basic knowledge and skills into a process of learning how to study. Close attention should be paid to the students' learning interests and experience and comprehensive courses should be arranged in order to meet different students' needs. Teachers are required to actively interact with the students so that the teaching process is a process of intercourse far from being a process of cognition. Although students are not in the centre, the status has been improved, and they have become the main body in education.

\section{CONCLUSION}

In sum, whether or not child-centred education is the most appropriate and most practical one still need time and evidence to underpin. However, it is a fact that education has been developing as child-centred education has challenged the traditional practice. Teaching now is more concerned with students rather than teachers. Students are no longer puppets which completely act by order of teachers. On the contrary, they behave more independently and have much more freedom. Close attentions have been paid to their interests and needs, which are in high child-centred education's agenda. The key point here is to what extent children's interests and needs should be emphasized on. The function of teacher should not be neglected. It should be combination between the two. Instructions by teachers should not be supplanted but supplemented.

\section{REFERENCES}

[1] Darling, J. (1994) Child-Centred Education and Its Critics. London: Paul Chapman Publishing Ltd.

[2] Dearden, R, F. (1968) The Philosophy of Primary Education. London: Routledge\&Kegan Paul.

[3] Dearden, R, F, Hirst, P, H \& Peter, R, S. (1972) A Critique of Current Educational Aims. London \& Boston: Routledge\&Kegan Paul. 
[4] Dearden, R, F. (1976) Problems in Primary Education. London, Henley and Boston: Routledge \& Kegan Paul.

[5] Dewey, J. (1916) Democracy and Education. New York: Macmillan.

[6] Hirst, P, H \& White, P. (1998) Philosophy of Education. London: Rouledge.

[7] Kirk, G. (1982) Curriculum and Assessment in the Scottish Secondary School. London: Ward Lock Educational.

[8] McCulloch, G. (1997) 'Privatizing the Past?' British Journal of Educational Studies, 45, 69-82.

[9] Rousseau, J. (1762) Emile. New York: Basic Books. 37-45.

[10] Schoenhals, M. (1993) The Paradox of Power in a People's Republic of China Middle School. New York: M. E. Sharpe.

[11] Wilson, P, S. (1998) Interests. In Hirst, P, H \& White, P. (ed) Philosophy of Education. London: Rouledge, 268-294. 